\section{Role of the Inorganic Constituents of Wheat Bran Extract in Streptomycin Production}

WHEAT bran has been frequently used as an ingredient in media for culturing micro-organisms. Good results have been recorded from this laboratory for penicillin production by $P$. notatum ${ }^{1}$ and streptomycin formation by $S$. griseus ${ }^{2}$. Detailed systematic investigations carried out to discover the factors in wheat bran extract responsible for these results have shown that the ash of the extract is mainly concerned so far as streptomycin is concerned.

Streptomycin fermentations were conducted in a manner described previously ${ }^{a}$. Streptomycin titre and the reaction of the culture fluids were studied daily. Antibiotic activity was determined from a standard curve obtained by the cup plate method. The following media were used:

I. Aqueous extract of wheat bran with total solids adjusted to 2 gm. per 100 ml; ; pre-adjusted to $p \mathrm{H} 6.8$.

II. 'Difco' peptone, $0.5 \mathrm{gm}$.; glucose, $1.0 \mathrm{gm}$.; sodium chloride, $0.5 \mathrm{gm}$.; distilled water, to $100 \mathrm{ml}$; pre-adjusted to $p$ H 6.5-7.

The inoculum consisted of a spore suspension of a Waksman's strain of $S$. griseus. The ash of the wheat bran extract was obtained by heating the total solids in an electric furnace at a temperature of about $1,000^{\circ} \mathrm{C}$. for $10-14$ hours. No attempt was made to dissolve the ash before adding it to the medium.

The accompanying table shows that addition of the ash at $500 \mathrm{mgm}$. per $100 \mathrm{ml}$. to medium II increased the streptomycin production to practically the same as that when $S$. griseus was grown in medium $I$. The ash content of medium $I$ is $453 \mathrm{mgm}$. per 100 c.c.

Effect of wheat bran extract ash on streptomycin formation

\begin{tabular}{|c|c|c|c|c|c|c|c|c|c|c|c|}
\hline \multirow{2}{*}{$\begin{array}{l}\text { Med- } \\
\text { ium }\end{array}$} & \multirow{2}{*}{$\begin{array}{c}\text { Ash in } \\
\text { medium } \\
\text { (mgm.l } \\
100 \text { c.c. })\end{array}$} & \multicolumn{5}{|c|}{$\begin{array}{c}\text { Reaction of medium } \\
\text { (days) }\end{array}$} & \multicolumn{5}{|c|}{$\begin{array}{l}\text { Streptomycin in } \\
\mu \mathrm{gm} \text {. per ml. }\end{array}$} \\
\hline & & 45 & $\overrightarrow{6}$ & & 8 & 9 & 4 & 5 & 6 & 7 & 89 \\
\hline II & $\begin{array}{c}\text { Nil } \\
\text { Nil } \\
100 \mathrm{mgm} . \\
200 \quad, \\
400 \quad,, \\
500 \quad,\end{array}$ & $\begin{array}{l}7.17 \\
6.9 \\
7.17 \\
7.37 \\
7.4 \\
7.5 \\
7.5\end{array}$ & & & & & & $\begin{array}{l}111 \\
24 \\
28 \\
28 \\
28 \\
28\end{array}$ & $\begin{array}{r}114 \\
25 \\
36 \\
45 \\
54 \\
61\end{array}$ & & \\
\hline
\end{tabular}

A similar observation regarding the role of inorganic constituents of corn-steep liquor in penicillin formation has been recorded4. Recently fatty acid-like components have been isolated ${ }^{8}$ from solid wheat bran, and it has been suggested that these might explain the good antibiotic production by micro-organisms in wheat bran. Neither the aqueous extract of wheat bran used by us nor its petrol-soluble fraction has shown any antibacterial activity. The data presented above suggest that the good yields obtained by using the bran or its aqueous extract is independent of any influence likely to result from the antibacterial activity of the fatty acid component of the bran. Further work regarding the role of the different elements present in the ash is in progress.

My thanks are due to Dr. K. M. Pandalai for his suggestions, to Prof. V. Subrahmanyan for his interest, and to Merck and Co., Rahway, N.J. I acknowledge the financial support from the Council for Scientific and Industrial Research, India.

R. Raghunandana RaO

Department of Biochemistry,

Indian Institute of Science,

Bangalore. May 17.

1 Sreenivasa Rao, S., Nature, 154, 83 (1944).

${ }^{2}$ Raghunandana Rao, R., et al., (in the press).

' Raghunandana Rao, R., et al., Nature, 158, 241 (1946).

Knight, Science, 102, 6 (1945).

Humfeld, H., J. Bact., 54, 513 (1947).

\section{Inhibition of a Succinic Aerodehydrogenase System by Surface-active Agents}

A NUMBer of detergents of different types have been found to depress the oxygen uptake of a homogenate of rabbit liver in presence of succinate (see accompanying table).

\begin{tabular}{|c|c|c|c|c|}
\hline Compound tested & $\begin{array}{l}\text { Class of } \\
\text { deter- } \\
\text { gent }\end{array}$ & $\begin{array}{c}\text { Oxygen } \\
\text { uptake } \\
1 / \mathrm{ml} . / \\
30 \mathrm{~min} .\end{array}$ & $\begin{array}{l}\text { Concen- } \\
\text { tration of } \\
\text { compound }\end{array}$ & hibition \\
\hline $\begin{array}{l}\text { Sodium cetyl } \\
\text { sulphate }\end{array}$ & anionic & 45 & $\begin{array}{l}M / 1,5000 \\
M / 7,500\end{array}$ & $\begin{array}{l}70 \\
16\end{array}$ \\
\hline $\begin{array}{l}\text { Sodium salt of iso- } \\
\text { propyl-substituted } \\
\text { naphthalene-sulph- } \\
\text { onic acid }\end{array}$ & anionic & 100 & $\begin{array}{l}M / 300 \\
M / 1,500\end{array}$ & $\begin{array}{l}62 \\
25\end{array}$ \\
\hline $\begin{array}{l}\text { Bile salts. (Sodium } \\
\text { taurocholate, sodium } \\
\text { glycocholate, mol. } \\
\text { wt. taken as } 500 \text { ) }\end{array}$ & anionic & 52 & $\begin{array}{l}M / 300 \\
M / 1,500\end{array}$ & $\begin{array}{l}97 \\
39\end{array}$ \\
\hline $\begin{array}{l}\text { Cetyl polyethylene- } \\
\text { oxide }\end{array}$ & neutral & 54\{ & $\begin{array}{l}M / 7,500 \\
M / 200,000\end{array}$ & $\begin{array}{l}88 \\
33\end{array}$ \\
\hline $\begin{array}{l}\text { Cetyl trimethyl } \\
\text { ammonium chloride }\end{array}$ & cationic & 131 & $\begin{array}{l}M / 500 \\
M / 2,500 \\
M / 12,500\end{array}$ & $\begin{array}{r}98 \\
40 \\
-32 *\end{array}$ \\
\hline $\begin{array}{l}\text { Dodecyl pyridinium } \\
\text { bromide }\end{array}$ & cationic & 97\{ & $\begin{array}{l}M / 500 \\
M / 2,500\end{array}$ & $\begin{array}{l}100 \\
-22\end{array}$ \\
\hline
\end{tabular}

- Stimulation of 32 and 22 per cent respectively.

The functioning of the enzyme system studied appears to be profoundly disturbed by a change in the surface activity of the preparation irrespective of the specific nature of the substances producing this change.

My thanks are due to I.C.I. (Dyestuffs), Ltd., for gifts of chemicals.

College of Technology,

DONALD HOCKENHULL

Manchester 1.

\section{Vascular Wilt Disease of Oil Palms in Nigeria}

Is 1946, I observed and diagnosed a vascular wilt disease of oil palms (Eloeis guineensis) in the Belgian Congo, a strain of Fusarium oxysporum being consistently associated with the necrosed wood vessels 1,2 An investigation in 1947 of diseased oil palms in various Nigerian plantations by Messrs. S. de Blank and F. Ferguson, of the United Africa Co., led them to the conclusion (private report) that vascular wilt disease was also present in Nigeria. Cultures which they submitted to me for identification consisted of strains of $F$. oxysporum very similar to those which I obtained in the Belgian Congo. During the present year, in an inspection of oil palm plantations in Nigeria, I obtained full confirmation of the presence of vascular wilt disease. Some plantation areas show how severe this disease can be, many 8-12 years old palms being killed off, together with the younger replacements. An important addition to our know ledge is that infected vascular strands can be observed in seedlings 18-24 months old: from these, Fusarium oxysporum and other species of Fusarium have been isolated. This fact may materially shorten the programme of breeding resistant varieties.

In Nigeria, as in the Belgian Congo, a leaf disease known as patch yellow has also an associated strain 